\title{
2 人部屋養護老人ホーム入居者の同室者との関係からみた空間利用の特性 \\ STUDY ON SPACE USE AT THE HOME FOR THE ELDERLY FOCUSED ON THE EFFECTS OF ROOM-SHARING
}

\author{
寺川優美*, 外山 義**, 三浦 研*** \\ Yumi TERAKAWA, Tadashi TOYAMA and Ken MIURA
}

\begin{abstract}
This study focused on effects of room-sharing on the space use of residents at the home for the elderly. Compared with nursing homes, their ADL levels are higher, dementia levels are milder, and effects of care conditions weigh less. Therefore, they are appropriate for the subject of investigation of the space use chosen by their own decisions. The results are as follows:

1. If one of roommates tends to stay at his or her room, another tends to stay at a public space.

2. The residents use only the half of their rooms, and make their own territory.

3. They have more frequent communications with residents in other rooms than roommates.
\end{abstract}

Keywords: The home for the elderly, Space use, Room-sharing, Territory, Communications with others 養護老人ホーム, 空間利用, 部屋の共有, テリトリー，他者との関わり

\section{1. 研究の背景と目的}

日本は、「高齢化社会」から「高齢社会」に移行し、そして今「超 高齢社会」に突入しつつある。要介護高齢者の急増に対応するため、

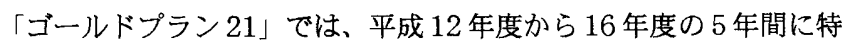
別盖護老人ホーム（以下、特盖） 36 万人分、老人保健施設 29.7 万 人分、痴呆性老人グループホーム 3,200 か所、ケアハウス 10.5 万人 分等が新規整備目標として揭げられている。近年ではこれらの施設 が「生活の場」であり、「終の住処」であるという点が配慮されるに 至り、平成 7 年に特盖の 1 人あたりの補助基準面積が引き上げられ たのを契機として個室化の動きが活発化する等、居住環境としての 質的向上が急務とされている。

これと並行して、施設に「住まう」主体である入居者の視点に立 脚した調查研究が数多くなされるようになり、建築計画の分野では、 特に、施設入居者がどのように空間を利用し個人的領域を形成して いくのかについて把握し、建築計画にフィードバックすることが強 く求められている。既往研究の大半が特別養護老人ホームを調査対 象としているか゚、本研究では養護老人ホーム ${ }^{1}$ （以下、盖護）を調 查対象として取り上げた。その理由は次の 3 点である。

1. 介護保険制度の導入から 1 年が経過し、制度の問題点がマスコ ミで指摘されている。その論点の 1 つとして、在宅での居住継続
が困難であるが、要介護度により施設入所ができない高齢者が多 数存在している実態がある。養護老人ホームは介護保険対象外施 設であるため、今後これらの高齢者を受け入れる施設としての重 要性が増してくると予測される。

2. 特養と比較すると、養護入居者の自立度は高く、痴呆度は低い こと、さらに身体介助を要する入居者が少ないため介護方針の影 響を受けにくいことから、入居者自らによる滞在場所の選択を考 察するのに適している。

3. 物的環境、特に建築計画は入居者の空間利用に影響を与えるが、 居合わす他の入居者が与える影響も無視できない。特養の多床室 ではベッドやカーテン等の設置により、個人の居場所が予め設定 されていることが多いが、養護の居室内ではこのような居場所の 規定がないことから、他者、特に同室者との関係が入居者の居場 所に与える影響を考察することが可能である。

入居者の空間利用特性及び個人的領域形成についての既往の研究 では、個室型特盖を調査対象とした、檑（1997）による、入居者が 環境に働きかけ、時間を掛けて個人的領域を形成していく過程を明 らかにした研究 ${ }^{2}$ 、井上(1997)による、物的環境に加え、対人関係 が入居者の個人的領域形成に与える影響を考察した研究 ${ }^{3)}$ 、柿沢 (1997)による、「集まり」の場としての共用空間のあり方を考察した
京都大学大学院工学研究科環境地球工学専攻 博士課程・工修

** 京都大学大学院工学研究科環境地球工学専攻 教授·Ph. D.

****京都大学大学院工学研究科環境地球工学専攻 助手. 工博
Graduate Student, Graduate School of Engineering, Kyoto Univ., M. Eng.

Prof., Graduate School of Engineering, Kyoto Univ., Ph. D.

Research Assoc., Graduate School of Engineering, Kyoto Univ., Dr. Eng. 
研究4)等がみられる。養護老人ホームを調査对象とした研究について みると、斉藤(1998) ${ }^{5}$ は、 2 人部屋で構成される養護と個室で構成さ れる軽費老人ホームとの比較から、2人部屋による施設内交流への弊 害を指摘している。また、児玉 $\left.(1988)^{6}\right)$ は一連の研究により、建築ク レームの増加が入居者のモラールを低下させることを明らかにし、 建築クレームを減少させるために必要な建築条件を提示している。 特盖と比較すると養護入居者は自立度が高く痴呆度が低いため空間 利用特性に顕著な差があると考えられるが、行動観察から養護入居 者の空間利用を定性的に扱った研究は見あたらない。

本研究では、 2 人部屋で構成される養護を調査対象として、入居者 の空間利用および領域形成の特珄を、同室者との関係に着目して明 らかにすることから、今後全国的に展開される養護の建て替えにお ける建築計画上の示唆を得ることを目的としている。

\section{2. 鲷查概要}

調査対象施設は、平成 13 年度に建て替えが計画されている $\mathrm{A}$ 盖 護である。入居者 50 人の内、 2 人部屋に居住する 44 人を分析対象 としている。7時から 19 時までの 12 時間、10分毎に各入居者の滞 在場所・姿勢・行為を観察・記録した。居室内での家具及び飾り付 けの種類及び位置の採集・写真撮影により居室内のしつらいを把握 した。入居者属性は、本人及び寮母へのインタビューにより把握し た。

調査対象者の基本属性を表 1 に、A 養護の概要を表 2 に示す。

\section{3. 滞在場所を規定する要因}

入居者の滞在場所を規定する要因を考察するにあたり、観察され た全滞在場所から、場所が予め規定されているプログラム（食事・入 浴・体操）及び通院のための外出を除外して、入居者自らが選択し た滞在場所のみを抽出した上で分析を行う。

\section{3-1．属性別に見る滞在場所の特街}

滞在場所を、自室、談話スペース (談話室・喫煙室・お茶コーナ一)、 廊下・屋外の 3 つに分類し、属性（性別 - 年齢 - 入居期間・歩行能 力・痴呆度）毎に、入居者の带在率を示したのが表 3 である。

性別及び入居期間による大差はみられない。

\section{表 1 調查対象者の基本属性}

\begin{tabular}{|c|c|}
\hline 性別 & 男18人 女26人 \\
\hline 平均年齢 & 80.3才（男77.1才 女82.9才） \\
\hline 入居期間 & 平均7年5ヶ月（最短4ヶ月〜最長24年） \\
\hline 歩行能力 ${ }^{7}$ & 自力歩行25人 補助歩行 $19 人$ \\
\hline 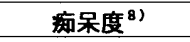 & | $\cdot 23$ 人 $\quad|| \cdot 14$ 人 $\quad|| \mid \cdot 5 人 \quad$ N.2人 \\
\hline 就寝形態 & ふとん就寝34人 ベッド就寝10人 \\
\hline \multicolumn{2}{|c|}{ 表2 調查対象施設の概要 } \\
\hline 所在地 & 秋田県北秋田郡A町 \\
\hline 開設年月 & 昭和28年10月 \\
\hline 延床面積 & $1,321 \mathrm{~m}^{2}$ \\
\hline 居室構成 & $\begin{array}{l}1 \text { 人部屋 } \times 1,2 \text { 人部屋 } \times 23,3 \text { 人部屋 } \times 1 \\
\text { ショートステイ用 } 2 \text { 人部屋 } \times 1\end{array}$ \\
\hline $\begin{array}{c}\text { 定員 } \\
\text { （調查時入居者数 }\end{array}$ & 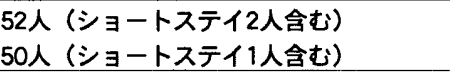 \\
\hline 調查日 & $\begin{aligned} \text { 2000年3月6日（行動観察調查） } \\
\text { 3月7日（估室のしつらい調查 · }\end{aligned}$ \\
\hline
\end{tabular}

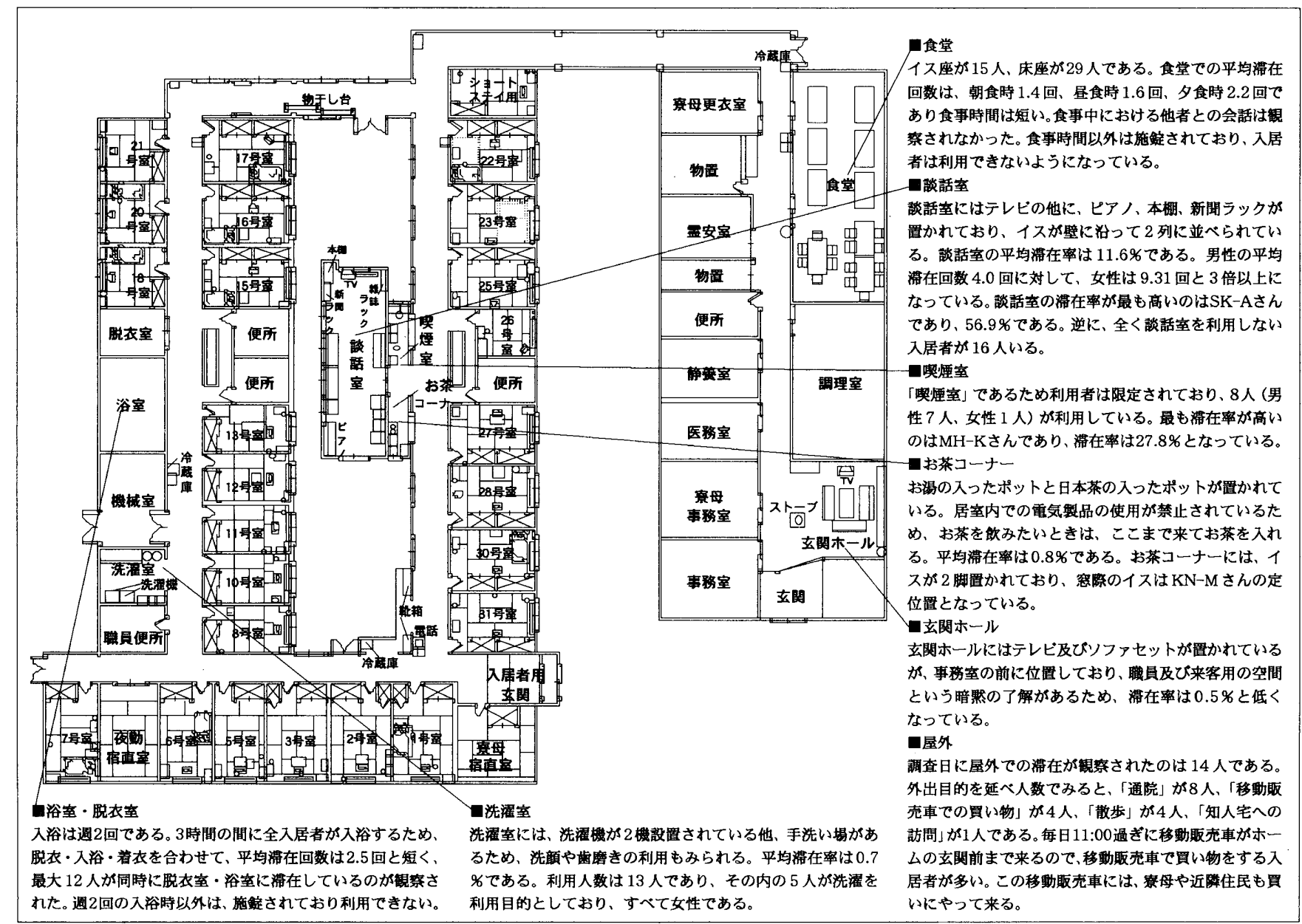


年齢についてみると、 60 代では、廊下・屋外の滞在率が自室滞在 率を上回っているが、70 代以上では逆転しており、高齢になるに従 い自室に滞在する傾向がある。（図 2)

自力歩行可能者の自室滞在率が $50.0 \%$ あるるのに対し、歩行に補 助を要する者（杖・手押し車の使用及びつたい歩き）は $68.5 \%$ と高 くなっていることから、歩行能力の衰退に伴い、自室に滞在する傾 向がみられる。(図 3)

痴呆度 $\mathrm{N}$ が 2 人のみであるため、疾呆度 I 〜 III で比較すると、疾 呆が重くなるに従い、自室滞在率が減少し、談話スペース滞在率が 増加している。(図 4)

各属性（性別・年齢・入居期間・歩行能力・痴呆度）毎に自室滞 在率との相関係数を算出した結果が表 4 である。

相関性が最も強いのが年齢であり、次いで歩行能力となっており、 年齢が高くなるほど、歩行能力が衰退するほど自室に滞在する傾向 がある。入所期間及び痴呆度では性別により正負の相関に分かれた が、男性では入所期間が長くなるほど、疾呆度が重くなるほど、自 室滞在率が増加するのに対し、女性ではその逆となっている。

\section{3-2． 同室者の存在が滞在場所に与える影篦}

同室者との関係が滞在場所に与える影響について考察する。

自室滞在率が $50 \%$ 以上入居者を「自室滞在型」、50\%未満の入 居者を「共用空間滞在型」と分類した結果、「自室滞在型」が 27 人、 「共用空間滞在型」が 17 人となった。

部屋別に、同室者 2 人の滞在場所型の組み合わせをみると、「自室 滞在型十共用空間滞在型」（以下「自室十共用型」）が最も多く13 室 であり、 $59.1 \%$ 占める。次いで、「自室滞在型＋自室滞在型」(以 下「自室十自室型」) が 7 室 $(31.8 \%)$ 、「共用空間滞在型+共用空間 滞在型」(以下「共用十共用型」) が 2 室（9.1\%）となっている。「自 室十自室型」は平均年齢が相対的に高く、「共用十共用型」は入居期 間が短く疾呆度が重いという特徵がみられた。(表 5)

2 人部屋 22 室の内、同室者の少なくとも 1 人が自室滞在型である のは 20 室であり、全体の9割以上を占める。その内の $65 \%$ 「自室 十共用型」であることから、同室者 1 人が自室を中心として带在し ている場合、もう片方の同室者は自室以外で滞在するという傾向が よタとれる。

では、「自室十共用型」において、同室者 2 人の内どちらが自室に 滞在する傾向にあるのかを分析すると、同室者 2 人を比較して高齢 である方が自室滞在型であるのは 13 室中 10 室であり、76.9\%を占 める。

\section{4. 居室内での起居様式の特徵}

居室内での起居様式を就寝形態別にみる。

調査対象者 44 人の内、ベッド就寝者が 10 人、ふとん就寝者が 34 人である。9

表6はベッド就寝者の居室内での起居様式を把握したものである。 ベッド就寝者が居室滞在時にベッド上にいる割合は $83.6 \%$ と 8 割以 上を占めており、ベッドの設置による場所の定位性がみられた。こ れは居室が狭いことに加え、入居者による家具の持ち込みが禁止さ れており、イスやソファ等の座家具を使用できないことが一因と考 えられる。

表 7 にベッド上で観察された行為内容を示す。ベッド上では睡眠
表3 帯在率の比較

\begin{tabular}{|c|c|c|c|c|c|}
\hline & \multirow[b]{2}{*}{ (人数) } & \multicolumn{3}{|c|}{ 滞在率 } \\
\hline & & & 自室 & 談話スペース & 碽下·屋外 \\
\hline \multicolumn{2}{|r|}{ 全体 } & (44人) & $58.1 \%$ & $14.6 \%$ & $27.3 \%$ \\
\hline \multirow{2}{*}{ 性別 } & 男 & （18人） & $57.4 \%$ & $11.9 \%$ & $30.7 \%$ \\
\hline & 女 & (26人) & $58.6 \%$ & $16.4 \%$ & $25.0 \%$ \\
\hline \multirow{4}{*}{ 年龄 } & 60代 & (6人) & $34.0 \%$ & $21.8 \%$ & $44.2 \%$ \\
\hline & 70代 & （12人） & $54.2 \%$ & $17.8 \%$ & $27.9 \%$ \\
\hline & 80代 & （22人） & $64.4 \%$ & $11.6 \%$ & $24.0 \%$ \\
\hline & 90代 & （4人） & $68.5 \%$ & $12.1 \%$ & $19.4 \%$ \\
\hline \multirow{4}{*}{$\begin{array}{l}\text { 入居 } \\
\text { 期間 }\end{array}$} & 5年末満 & （21人） & $53.8 \%$ & $17.0 \%$ & $29.1 \%$ \\
\hline & 5年～10年 & （10人） & $60.4 \%$ & $14.8 \%$ & $24.8 \%$ \\
\hline & 10年～15年 & （6人） & $60.7 \%$ & $10.2 \%$ & $29.1 \%$ \\
\hline & 15年以上 & (7人) & $64.4 \%$ & $11.6 \%$ & $24.0 \%$ \\
\hline \multirow{2}{*}{$\begin{array}{l}\text { 步行 } \\
\text { 能力 }\end{array}$} & 自力歩行 & （25人） & $50.0 \%$ & $19.4 \%$ & $30.6 \%$ \\
\hline & 㭪助步行 & (19人) & $68.5 \%$ & $8.5 \%$ & $23.0 \%$ \\
\hline \multirow{4}{*}{$\begin{array}{c}\text { 痴呆 } \\
\text { 度 }\end{array}$} & 1 & （23人） & $59.9 \%$ & $10.8 \%$ & $29.3 \%$ \\
\hline & 11 & （14人） & $56.5 \%$ & $16.0 \%$ & $27.5 \%$ \\
\hline & III & （5人） & $51.9 \%$ & $32.3 \%$ & $15.8 \%$ \\
\hline & IV & (2人) & $65.0 \%$ & $1.6 \%$ & $33.3 \%$ \\
\hline
\end{tabular}
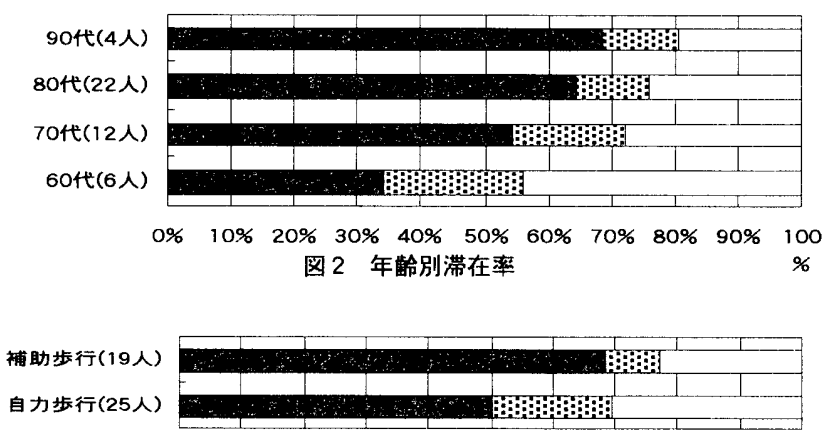

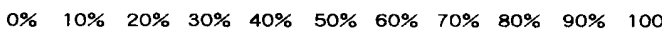
図 3 歩行能力別滞在率

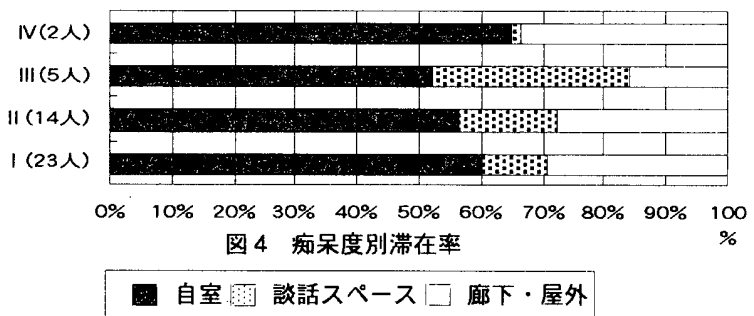

\begin{tabular}{|c|c|c|c|c|c|}
\hline & 性別 & 年軨 & 入居期間 & 歩行能力 & 痴呆度 \\
\hline 全体 & 0.029 & 0.414 & 0.119 & 0.405 & -0.056 \\
\hline 男 & & 0.524 & 0.416 & 0.416 & 0.263 \\
\hline 女 & & 0.361 & -0.074 & 0.408 & -0.335 \\
\hline
\end{tabular}

表5 部屋別滞在場所型組み合わせにみる基本属性

\begin{tabular}{|c|c|c|c|c|c|c|}
\hline & \multicolumn{2}{|c|}{ 「自室十自室」 } & \multicolumn{2}{|c|}{ 「自室＋共用」 } & \multicolumn{2}{|c|}{ 「共用十共用」 } \\
\hline 組数 & 7 縕 & & 13 年 & & 2 & \\
\hline 平均年淽 & 83.3 & & 79.2 & & 79.8 & \\
\hline 平均入居年数 & 7 年6 & & 7年10 & & 49 & \\
\hline 歩行能力 & $\begin{array}{l}\text { 自力歩行 } \\
\text { 補助步行 }\end{array}$ & $\begin{array}{l}\text { 6人 } \\
\text { 8人 }\end{array}$ & $\begin{array}{l}\text { 自力歩行 } \\
\text { 補助歩行 }\end{array}$ & $\begin{array}{l}\text { 16人 } \\
\text { 10人 }\end{array}$ & $\begin{array}{l}\text { 自力歩行 } \\
\text { 補助歩行 }\end{array}$ & $\begin{array}{l}3 \hat{1} \\
1 \text { 人 }\end{array}$ \\
\hline 痴呆度 & $\begin{array}{c}\text { I } \\
\text { II } \\
\text { III } \\
\text { IV }\end{array}$ & $\begin{array}{l}\text { 7人 } \\
6 \hat{1} \\
\text { 1人 } \\
\text { 0人 }\end{array}$ & II & $\begin{array}{l}\text { 16人 } \\
7 \hat{1} \\
3 \hat{3} \\
4 \hat{1}\end{array}$ & II & $\begin{array}{l}0 \hat{1} \\
1 \hat{\lambda} \\
3 \hat{\lambda} \\
0 \hat{人}\end{array}$ \\
\hline
\end{tabular}

表6 ベッド就寝者（10人）の居室内での起居様式

\begin{tabular}{|c|c|c|c|c|c|c|c|}
\hline & $\begin{array}{l}\text { ベッドに } \\
\text { 蒋ている }\end{array}$ & $\begin{array}{l}\text { ベッド上に } \\
\text { 座っている }\end{array}$ & $\begin{array}{c}\text { ベッドに } \\
\text { 厢を脚ける }\end{array}$ & $\begin{array}{c}\text { 鳃に } \\
\text { 座っている }\end{array}$ & $\begin{array}{c}\text { 立って } \\
\text { (1る }\end{array}$ & $\begin{array}{l}\text { 䟩いर } \\
\text { いる }\end{array}$ & 合計 \\
\hline & 122 & 104 & Do & 12 & 44 & 8 & 050 \\
\hline & (31.3\%) & $(26.7 \%)$ & $(25.6 \%)$ & (3.1\%) & $(11.3 \%)$ & $(2.1 \%)$ & $(100 . c$ \\
\hline
\end{tabular}


以外に、TV 鑑賞、整理整頓、身だしなみ、飲食など様々な行為が行 われている。ベッド就寝者は、移動せずに行為目的が達せられるよ うに、ベッド横に茶ダンス、ゴミ箱などを配置して、自分の身の回 りのものを全て手の届く範囲に置く傾向がみられる。

ふとん就寝者は、ベッド就寝者とは異なり、移動が困難な者で あっても、這ったり転がったりして移動することにより、行為に応 じて居場所を選択している。ふとんを敷いた後の起居様式をみると、 9 割以上がふとん上で過ごしている。（表 8)

\section{5. 居室内における居場所の特幑ーテリトリーの形成}

ここでは、居室内での居場所について考察する。観察された全居 場所を居室平面図にプロットした結果（図 5)、入居者は居室の半分 しか使用していないことが明らかとなった。入居者は同室者と居室 内で棲み分けており、部屋の中心線上に暗黙の境界線が存在しテリ トリーを形成しているのである。

相手テリトリー滞在時の行為内容及びその回数を表 9 に示す。相 手テリトリー側での滞在が観察されたのは27回であり、入居者の自

\begin{tabular}{|c|c|c|c|c|c|c|c|}
\hline & \multirow{2}{*}{ 布団に } & \multirow{2}{*}{ 布団の上に } & \multirow{2}{*}{ 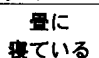 } & \multirow{2}{*}{$\begin{array}{c}\text { 曋に } \\
\text { 座っている }\end{array}$} & \multirow{2}{*}{$\begin{array}{l}\text { 立って } \\
\text { いる }\end{array}$} & \multirow{2}{*}{$\begin{array}{l}\text { 步いて } \\
\text { いる }\end{array}$} & \multirow[b]{2}{*}{ 合計 } \\
\hline & & & & & & & \\
\hline 観察 & 147 & 53 & 0 & 6 & 15 & 0 & 221 \\
\hline (割合) & (66.5\%) & $(24.0 \%)$ & $(0.0 \%)$ & (2.7\%) & $(6.8 \%)$ & $(0.0 \%)$ & $(100.0 \%)$ \\
\hline
\end{tabular}

表7 ペッド就寝者のペッド上での行為

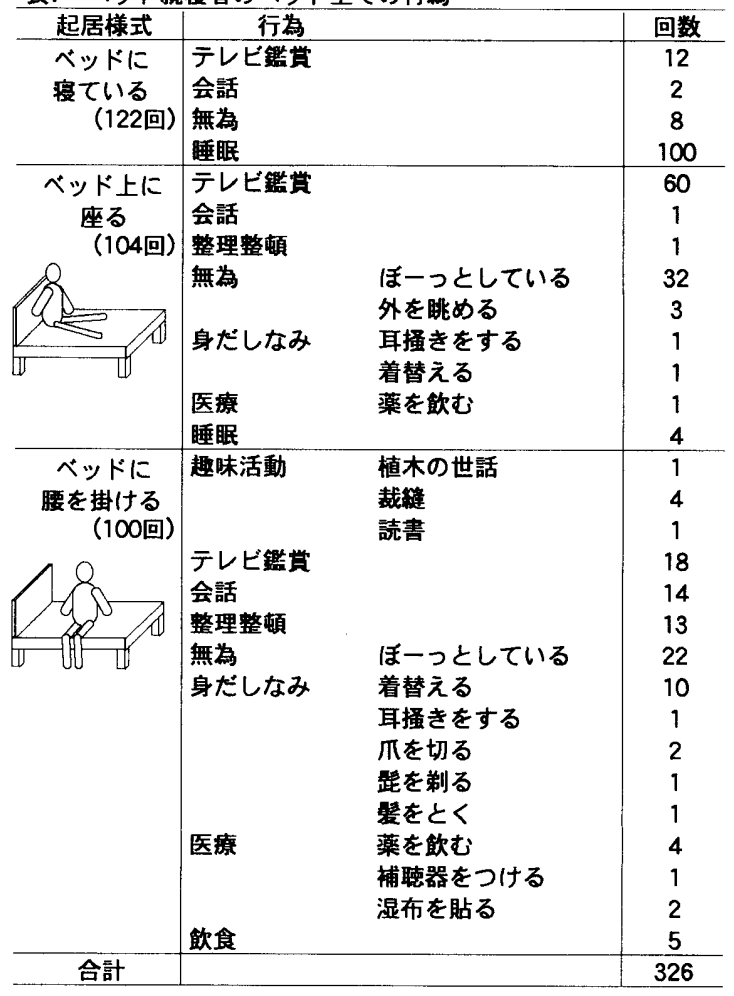

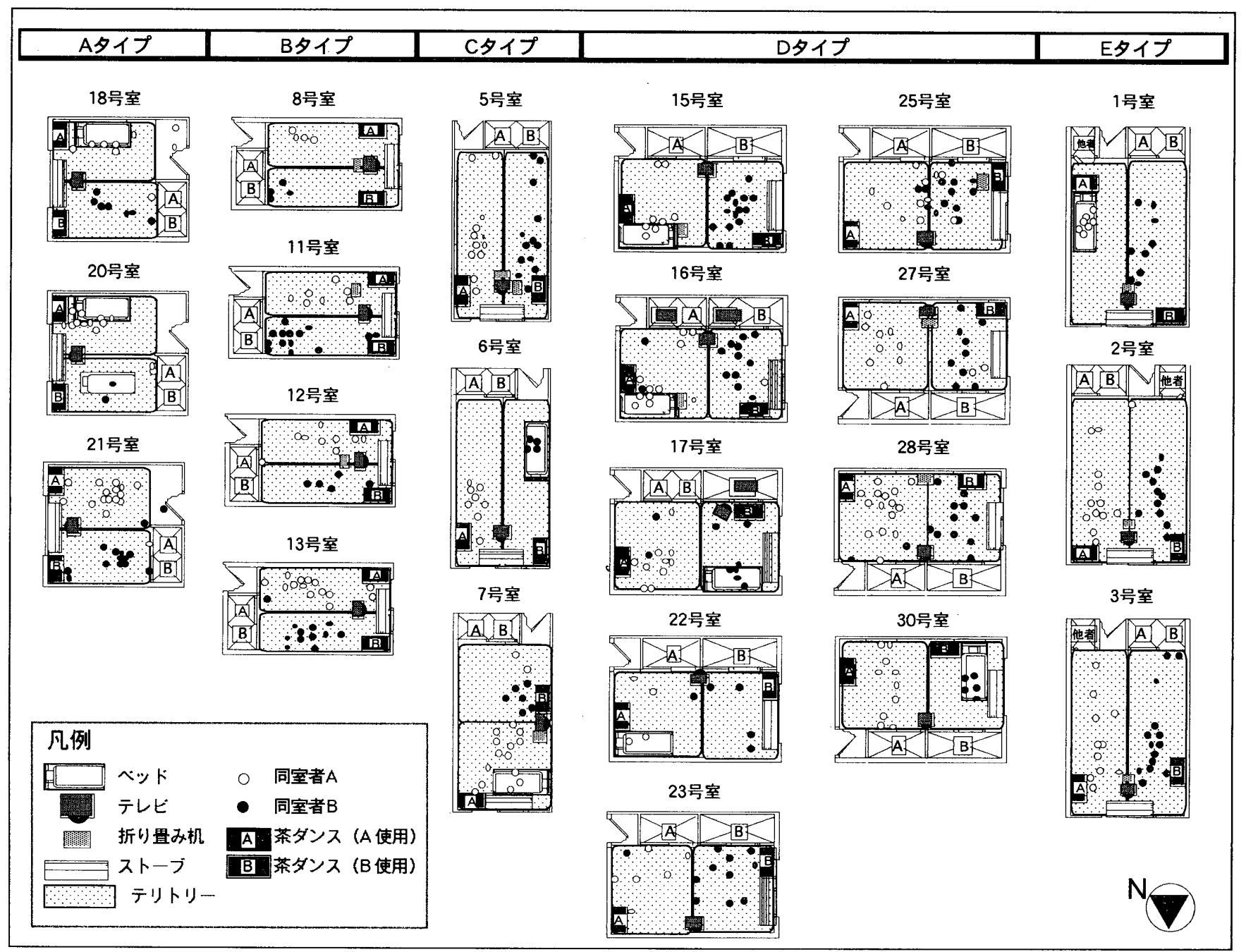

図 5 居室内での居場所とテリトリー位置 
室滞在回数 1,473 回の $1.8 \%$ に過ざない。27 回の内の 6 割は、入退 出のための移動、押入から物を出す等、場所と結びついた行為であ る。

居室は、表 10 に示すように室規模及び押入の位置により 5 タイプ に分類することができる。居室タイプ毎に観察されたテリトリーの 位置を示したのが図 5 である。7号室の 1 事例を除外すると、テリト リーの位置は、室規模・形状、方位、開口部の位置に関係なく、押 入の位置に規定されている。入居者は自分が使用している押入侧を 自分のテリトリーとして使用しており、施設から配られる茶ダンス

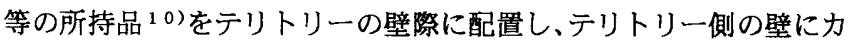
レンダーや洋服を措けたり、飾り付けを行っている。互いのテリト リーが接する境界線上に 2 人で共有するテレビ及び折り畳み机を配 置する傾向がみられる。(共用の折り畳み机が片方のテリトリーに占 有された時に、同室者間でもめ事が発生した事例が報告されてい る。）居室内にカーペットを敷いている事例が 3 例あるが、いずれも 自分のテリトリー側にしか敷いていない。前項でベッド使用者が ベッド上のみで過ごす傾向があることを示したが、この場合でも境 界線は部屋の中心である。

\section{6. 他者との関わり}

ここでは、入居者が誰とどの程度関わり ${ }^{11)}$ をもているのかにつ いてみる。

他者との関わりが観察されたのは延べ相手人数 ${ }^{12)} 285$ 人であり、 1 入居者当たり 6.48 人となる。寮母等との関わりを除外して入居者 との関わりに限定すると、延べ相手人数は 247 人、1 入居者当たり 5.61 人となり、これを男女別にみると、女性の 7.58 人に対し男性は 2.78 人と少なく、特に同室者との関わりに顕著な差がみられる。(表 11)

他の入居者との関わりが全く観察されなかった入居者は 10 人（男 性 6 人、女性 4 人) であり、全体の $1 / 4$ 近くを占める。その内の 6 人 は、寮母等を含めても誰とも関わりをもっていない。関わりのあった 入居者延べ相手人数が 3 人以下である入居者は 22 人と全体の半数を 占めており、他者との関わりの少ないことが分かる。（図6）

関わりの相手と関わりのもたれた場所を表 12 に示す。

関わりの相手についてみると、他室者が延べ相手人数で 147 人で あり、 $51.7 \%$ 之半数以上を占める。同室者は延べ相手人数で 100 人で $35.0 \%$ 、寮母等（寮母・看護婦・店員）との関わりは延べ相手人数 38 人、13.3\%となっている。入居者は同室者よりもむしろ他室者と頻繁 に関わりをもっている。

関わりのもたれた場所についてみると、自室が延べ相手人数 137 人

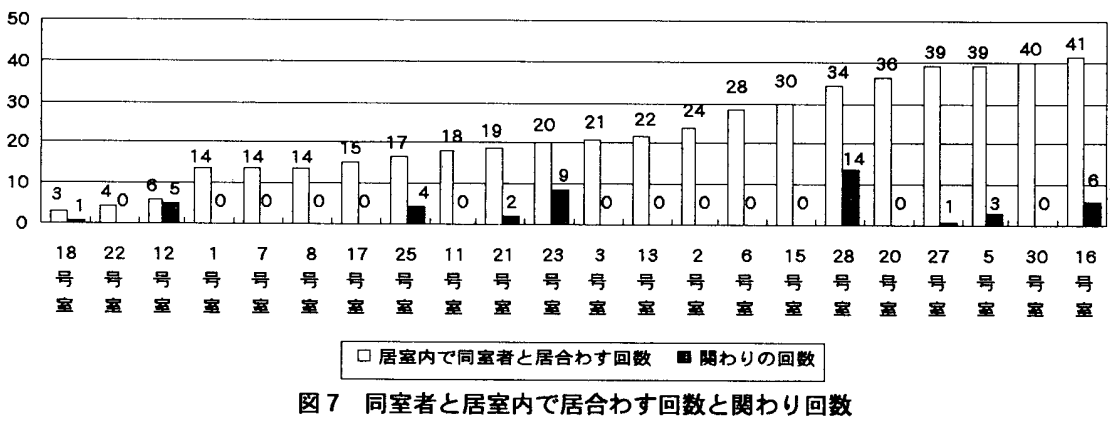

で約半数を占める。他室者との交流では、談話室が最も多く延べ相 手人数 47 人と $32.0 \%$ を占めるが、自室と他室者居室を合計すると延 べ相手人数 61 人で $41.5 \%$ を占めることから、入居者は互いの居室を 行き来して関わりをもつ傾向がタられた。

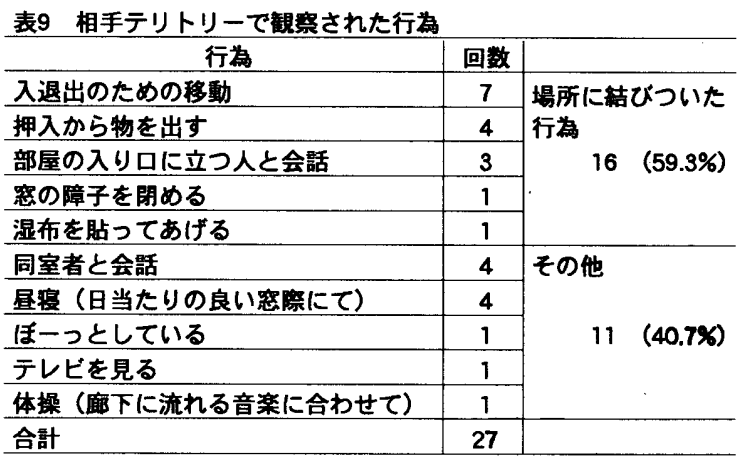

\begin{tabular}{|c|c|c|c|c|c|}
\hline & $\begin{array}{c}\text { Aタイプ } \\
\text { (3室) }\end{array}$ & $\begin{array}{c}\text { Bタイプ } \\
\text { (4室) }\end{array}$ & $\begin{array}{c}\mathrm{C} \\
\text { (3室) }\end{array}$ & $\begin{array}{c}D \\
\text { (9室) }\end{array}$ & $\begin{array}{c}E \\
\text { (3室) }\end{array}$ \\
\hline 室規模 & 6鲁 & 6異 & 7.5畳 & 7.5鰛 & 10畳 \\
\hline 押入の位圈 & 長辺侧 & 短辺侧 & 短辺㑡 & 長辺側 & 短召䁚 \\
\hline
\end{tabular}

\begin{tabular}{c|c|c|c}
\multicolumn{2}{l}{ 表11 } & 男女別入居者との関わり回数 \\
\hline & 同室者との関わり回数 & 他室者との関わり回数 & 合計 \\
\hline 男性 & 10 & 40 & 50 \\
& $(0.56)$ & $(2.22)$ & $(2.78)$ \\
\hline 女性 & 90 & 107 & 197 \\
& $(3.46)$ & $(4.12)$ & $(7.58)$ \\
\hline 合計 & 100 & 147 & 247 \\
& $(2.27)$ & $(3.34)$ & $(5.61)$ \\
\hline
\end{tabular}

下段の（）内は1入居者当たりの回数

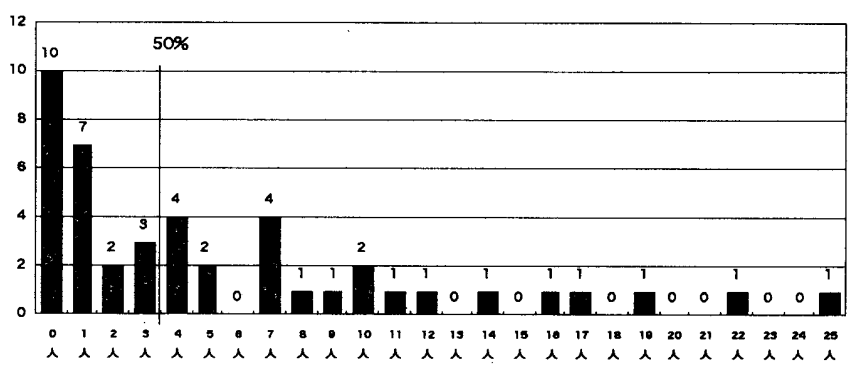

図 6 関わりのあった入居者延べ相手人数別入居者数

\begin{tabular}{|c|c|c|c|c|}
\hline & 同室者 & 他室者 & 尞母等 & 合計 \\
\hline 自室 & 88 & 34 & 15 & 137 \\
\hline & $88.0 \%$ & $23.1 \%$ & $39.5 \%$ & $48.1 \%$ \\
\hline 談話室 & $\begin{array}{c}2 \\
2.0 \%\end{array}$ & $\begin{array}{c}47 \\
32.0 \%\end{array}$ & $\begin{array}{c}2 \\
5.3 \%\end{array}$ & $\begin{array}{c}51 \\
179 \%\end{array}$ \\
\hline 喫煙室 & $\begin{array}{c}0 \\
0.0 \%\end{array}$ & $\begin{array}{c}5 \\
3.4 \% \\
\end{array}$ & $\begin{array}{c}0 \\
0.0 \%\end{array}$ & $\begin{array}{c}5 \\
1.8 \%\end{array}$ \\
\hline 医務室 & $\begin{array}{c}0 \\
0.0 \%\end{array}$ & $\begin{array}{c}2 \\
1.4 \%\end{array}$ & $\begin{array}{c}11 \\
28.9 \%\end{array}$ & $\begin{array}{c}13 \\
4.6 \%\end{array}$ \\
\hline 廊下 & $\begin{array}{c}10 \\
10.0 \%\end{array}$ & $\begin{array}{c}27 \\
18.4 \% \\
\end{array}$ & $\begin{array}{c}6 \\
15.8 \% \\
\end{array}$ & $\begin{array}{c}43 \\
15.1 \%\end{array}$ \\
\hline 他室者居室 & $\begin{array}{c}0 \\
0.0 \%\end{array}$ & $\begin{array}{c}27 \\
18.4 \% \\
\end{array}$ & $\begin{array}{c}2 \\
5.3 \%\end{array}$ & $\begin{array}{c}29 \\
10.2 \% \\
\end{array}$ \\
\hline その他 & $\begin{array}{c}0 \\
0.0 \%\end{array}$ & $\begin{array}{c}5 \\
3.4 \%\end{array}$ & $\begin{array}{c}2 \\
5.3 \%\end{array}$ & $\begin{array}{c}7 \\
2.5 \%\end{array}$ \\
\hline 合計 & $\begin{array}{c}100 \\
100.0 \% \\
\end{array}$ & $\begin{array}{c}147 \\
100.0 \% \\
\end{array}$ & $\begin{array}{c}38 \\
100.0 \%\end{array}$ & $\begin{array}{c}285 \\
100.0 \% \\
\end{array}$ \\
\hline
\end{tabular}


入居者との関わりの行為内容をみると、延べ相手人数 285 人の内、 会話が 273 人であり $95.8 \%$ を占める。会話以外に観察された行為は、 移動介助（車椅子を押す・手を引いて歩く）(延べ 8 人）、物を取る （延べ 4 人）、洋服を整える（延べ 4 人）となっている。寮母等との 関わりでは、会話以外に、薬をもらう、注射してもらうなどの医療 行為が観察された。

次に、同室者と同時に居室に滞在している時に限定して、同室者 間の関わりについてみる。図 7 は、居室内で同室者と居合わす回数 と関わりのあった回数を部屋别にみたものである。

同時居室滞在回数 498回の内、関わりが観察されたのは45回であ り、1 割にも満たず、1 部屋当たりでは 2.05 回でしかない。関わり が全く観察されなかったのは13室であり、59.1\%を占める。図7に 示すように、同時滞在回数が多いからといって関わり回数が多くな るというとことはない。ここで注意したいのは、関わりの回数が多 いから仲がよいといらわけではないことである。例えば、28号室で は関わり回数が14回と最多であるが、入居者から部屋替えの強い要 望が出ている。

\section{7. まとめ}

前章までの分析から、以下の 6 点が明らかにされた。

1. 入居者の滞在場所と属性との関連を考察した結果、高齢になる に従い、歩行能力が衰退するに従い、自室に滞在する傾向がみら れた。また、痴呆度が重くなるほど、自室滞在率が減少し、談話 スペース滞在率が増加している。

2. 部屋別に同室者 2 人の滞在場所型をみると、 2 人部屋 22 室の内、 同室者の少なくとも 1 人が自室滞在型であるのは 20 室であり 9 割 以上を占める。その内の $65 \%$ 「自室十共用型」であることから、 同室者の 1 人が自室を中心として滞在している場合、もう片方の 同室者は自室以外で滞在するという傾向がよみとれる。

3. 居室内の起居様式をみると、ベッド就寝者が居室滞在時にベッ ド上にいる割合は 8 割以上を占め、ベッド設置による場所の定位 性がみられた。これは、居室が狭いこと、家具の持ち込みが禁止 されているため、イスやソファ等の座家具が使用できないことが 一因であると考えられる。ふとん就寝者は移動が困難な者であっ ても、追ったり転がったりして移動することにより、行為に応じ て居場所を選択しているか゚、ふとんを敷いた後は 9 割以上をふと ん上で過ごしている。

4. 居室内での居場所を考察した結果、入居者は居室の半分しか使 用しておらず、部屋の中心線上に暗黙の境界線が存在し、テリト リーを形成していることが明らかとなった。このテリトリーの位 置は、室規模・形状、方位、開口部の位置に関係なく、押入の位 置に規定されている。入居者は自分が使用している押入側を自分 のテリトリーとしており、テリトリーの壁際に家具を設置し、壁 に飾り付けを行っている。

5. 他者との関わりについてみると、他の入居者との関わりが全く 観察されなかった入居者が10人いること、関わりのあった入居者 延べ相手人数が 3 人以下である入居者が 22 人と全体の半数を占め ることから、他者との関わりが極めて少ないことが分かった。ま た、入居者は同室者よりも、他室者との関わりを頻繁にもってお り、談話スペースよりも互いの居室を行き来して関わりをもって
いる。男女別にみると、男性は女性に比べて関わりが少なく、特 に同室者との関わりにおいて顕著な差がみられる。

6. 居室内に同室者 2 人が同時に滞在している回数 498 回の内、関 わりが観察されたのは 45 回であり、1 割にも満たず、1 1 部屋当た り2.05回でしかない。このように、同室者と居室で居合わす回数 が多いにも関わらず、同室者間での関わりは少ない。

以上みてきたように、同室者の 1 人が自室を中心として带在して いる場合、もう片方の同室者が自室以外で带在する傾向があること、 入居者は居室内でテリトリーを形成して、同室者と棲み分けている ことから、2人部屋で構成される養護老人ホームでは、同室者の存在 が施設内での滞在場所及び居室内での居場所に影響を及ぼしている ことが明らかになった。同室者よりも他室者との関わりがより頻繁 にもたれていることも含めて考えると、自分と同室者間の領域を分 け、同室者と極力関わりをもたないことは、閉じられた施設内にお いて狭い居室を他者と共有して暮らしていく上で、猙いを起こさな いための暗黙のルールと言えよう。

\section{8. 蓝護老人ホームの建築計画への示唆}

次に、以上の考察から今後全国的に展開されるであろう養護老人 ホーム建て替えの際に建築計画上求められる点を整理する。

1. 居室の個室化

現行の盖護老人ホーム建設基準では、居室定員は 2 人以下と なっている。狭い居室を他者と共有することにより、プライバ シーが確保できないのは勿論のことだが、狭い居室をさらに半分 しか使用しておらず、そしてそのために極力私物を少なくしてい る実態等を考慮すると、居室の個室化は必然である。入居者は他 室者と部屋を行き来して関わりをもっているが、個室化により同 室者に気兼ねする必要がなくなれば、施設内交流は活発になると 予測される。

2. 共用空間にバリエーションをもたせる

他者と関わる場所として、居室及び談話スペースが中心となっ ているが、廊下での関わりも $15.1 \%$ 占めている。これは、共用空 間において集まれる場が談話スペースや玄関ホール等に限られて いることが影響していると考えられる。また、談話室では、同時 に 3 人以上の入居者が関わっているのは 1 回しか観察されていな い。これは、談話室の壁に沿ってイスが2列に並べられており、交 流を生み出しにくい配置となっていることによると推察される。 入居者がシチュエーションに応じて滞在場所を選択できるよう、 共用空間にバリエーションをもたせるとともに、交流を促すよう な家具配置に配慮する必要がある。

3. 居室面積にゆとりをもたせる

調査対象の $\mathrm{A}$ 養護同様、他の高粗者福祉施設においても家具の 持ち込みを禁止している施設が多い。これは居室が狭いことも影 響していると考元られる。家具を自由に持ち込めるようになれば、 例えば、ベッド就寝者が座家具を使用することにより、行為に応 じて居場所を選択することも可能となる。家具は単に物を収容す るという機能だけではなく、自己のアイデンティティの確立にも つながることも考慮すると、家具の持ち込みを自由化するととも に、家具設置場所を確保できるよう、居室面積にゆとりをもたせ 


\section{る必要がある。}

\section{今後の課題と碀辞}

$\mathrm{A}$ 盖護は平成 13 年度に建て替えが計画されている。POE (使用後 調査）による比較から、今回考察した内容を再検証することを今後 の課題としたい。

居室内での行動観察に快くご協力いただいたA盖護入居者並びに 施設スタッフの皆様に、心からお礼を申し上げます。

【注积】

1）平成 11 年 10 月 1 日現在、全国に養護老人ホームは 949 施設あり、64,450 人が入居している。(出典 : 厚生労働省統計情報部「社会福祉施設調查」)

2) 参考文献 1 参照

3）参考文献 2 参照

4) 参考文献 3 参照

5) 参考文献 4 参照

6) 参考文献 5,6 参照

7）完全自力歩行が可能な場合を「自力歩行」、杖・手押し車の使用及びつた 光歩きの場合を「補助歩行」とした。

8）調查対象者の中には知的障害者 5 人、精神障害者 5 人、疾呆症 17 人が含ま れるが、Berger スケールにより一律に知的機能度を判定した。

9） $\mathrm{A}$ 養護では、ふとん就寝が基本であるが、立ち上がりが困難であり、かつ 入居者から要望があった場合、ベッドの設置を認めている。
10）施設から各入居者に茶ダンスが 1 、各居室にテレビ1、折り畳み机 1 が渡 される。入居者による家具の持ち込みが禁止されているため、収納できな い所持品は段ボールや紙袋に入れて収納している。

11）関わりとは、他者との間に交わされた具体的な行為とする。ただし、施設 プログラムである体操・ゲーム時における関わりは除外している。

12）同時に複数の人と関わりが観察された埸合、「延へ相手人数」としてそれ ぞれについてカウントしている。例えば、 $\mathrm{A}$ さんが同時にBさんとCさん と会話している場合、Aさんの関わりの延べ相手人数は2人である。

\section{【参考文献】}

1）霞弘志ほか 3 名 : 個室型特別養護老人ホームにおける個室内の個人的領域 形成に関する研究, 日本建築学会計画系論文集NO.500, P133-138, 1997年 10 月

2）井上由起子ほか 3 名: 高齢者居住施設における入居者の個人的領域形成に 関する考察,日本建築学会計画系論文集 NO.501, P109-115, 1997年11月

3）柿沢英之ほか 3 名 : 入所者のグループ形成とその特性に関する考察, 日本 建築学会計画系論文集 NO.493, P153-159, 1997 年 3 月

4）斉藤功子，西村一朗 : 羡護老人ホーム入所者の施設内外の交流と外出行動 に関する調查研究, 日本建築学会計画系論文集 NO.506, P61-68, 1998 年 4 月

5）児玉桂子：建築条件に対する居住者のクレーム分析，日本建築学会計画系 論文集 NO.385, P53-61, 1988 年 3 月

6）児玉桂子 : 居住者のモラールと心理的苦痛に及ぼす建築条件の影響, 日本 建築学会計画系論文集 NO.390, P77-85, 1988 年 8 月

(2001年 5 月 9 日原稿受理，2001年 6 月 19 日採用決定) 